Article

\title{
Contribution of Volcanic and Fumarolic Emission to the Aerosol in Marine Atmosphere in the Central Mediterranean Sea: Results from Med-Oceanor 2017 Cruise Campaign
}

\author{
Sacha Moretti ${ }^{1}$, Apostolos Salmatonidis ${ }^{2}$, Xavier Querol ${ }^{2}$, Antonella Tassone ${ }^{1}$, \\ Virginia Andreoli ${ }^{1}$, Mariantonia Bencardino ${ }^{1}$, Nicola Pirrone ${ }^{1}$, Francesca Sprovieri ${ }^{1}$ and \\ Attilio Naccarato ${ }^{1, *(D)}$ \\ 1 CNR-Institute of Atmospheric Pollution Research, Division of Rende, UNICAL-Polifunzionale, \\ I-87036 Arcavacata di Rende, CS, Italy; sacha.moretti@iia.cnr.it (S.M.); antonella.tassone@iia.cnr.it (A.T.); \\ virginia.andreoli@iia.cnr.it (V.A.); bencardino@iia.cnr.it (M.B.); pirrone@iia.cnr.it (N.P.); \\ f.sprovieri@iia.cnr.it (F.S.) \\ 2 Institute of Environmental Assessment and Water Research (IDÆA-CSIC), C/Jordi Girona 18, \\ 08034 Barcelona, Spain; apsgeo@cid.csic.es (A.S.); xavier.querol@idaea.csic.es (X.Q.) \\ * Correspondence: attilio.naccarato@iia.cnr.it
}

Received: 8 January 2020; Accepted: 27 January 2020; Published: 30 January 2020

\begin{abstract}
This work studied the contribution of the geogenic sources volcanoes and fumaroles to the aerosol in marine atmosphere in the central Mediterranean basin. For this purpose, in the framework of the Med-Oceanor measurement program, we carried out a cruise campaign in the summer of 2017 to investigate the impact to the aerosol of the most important Mediterranean volcanoes (Mount Etna, Stromboli Island, and Marsili Seamount) and solfatara areas (Phlegraean Fields complex, Volcano Islands, Ischia Island, and Panarea submarine fumarole). We collected $\mathrm{PM}_{10}$ and $\mathrm{PM}_{2.5}$ samples in 12 sites and performed chemical characterization to gather information about the concentration of major and trace elements, elemental carbon (EC), organic carbon (OC), and ionic species. The use of triangular plots and the calculation of enrichment factors confirmed the interception of volcanic plume. We integrated the outcomes from chemical characterization with the use of factor analysis and SEM/EDX analysis for the source apportionment. Anthropogenic and natural sources including shipping emissions, volcanic and fumarolic load, as well as sea spray were identified as the main factors affecting aerosol levels in the study area. Furthermore, we performed pattern recognition analysis by stepwise linear discriminant analysis to seek differences in the composition of $\mathrm{PM}_{10}$ and $\mathrm{PM}_{2.5}$ samples according to their volcanic or solfatara origin.
\end{abstract}

Keywords: Mediterranean Sea; particulate matter; volcanic area; air quality; carbonaceous compounds; element analysis

\section{Introduction}

Advancements in the current state of knowledge of atmospheric aerosols are an important research topic because of their implications in environmental and health issues [1]. Nowadays, much of the air pollution results from human activities, but natural sources also contribute to the increase of the exposure level of the population and ecosystem to the polluted air. Typically, the major natural emissions in terms of mass include sea spray $(84 \%)$ and mineral dust (13\%), along with other sources such as biological primary organic aerosols (POA), volcanic emissions, biogenic secondary organic aerosols (SOA), and biogenic sulfate particles [2]. Anthropogenic aerosols contribute only $2 \%$ to global 
emissions, mainly in the form of anthropogenic sulfate (49\%) and industrial dust (40\%), with additional emissions of anthropogenic nitrate, SOA, and fossil fuel-derived POA. On a global-scale, primary aerosols are dominant over secondary species (98\% vs. $2 \%$ ), whereas on the local-scale, this scenario is reversed [2]. Indeed, the source contributions to ambient aerosols may differ from one region to another since they are strongly affected by a broad spatial variability. Owing to the importance of aerosol investigation on both global and local scales, several international programs aim to assess its chemistry and interaction with the climate, e.g., Charmex (Chemistry-Aerosol Mediterranean Experiment) and IGAC (International Global Atmospheric Chemistry). The study and identification of events affecting air quality are complex tasks in which data handling strategies including aerosol maps, back-trajectory analysis, and receptor modeling support the laboratory analysis on the composition of particulate matter (PM). In this respect, the use of mass spectrometry technologies has been giving a considerable impulse allowing in-depth analyses and characterization of the PM [3] as well as other environmental matrices [4,5]. Natural contributions to the levels of ambient air particulate matter (PM) and their speciation in Europe have been characterized using different approaches in many studies [2,6-13]. The air quality of Mediterranean countries can be affected by four major natural sources of atmospheric aerosol, i.e., African dust, sea spray, wildfire, and volcanic emission [2]. The wind-blow African dust can increase ambient PM levels even above the PM thresholds [12-15], and its contribution that originates from arid and semiarid areas leads to an increase of mineral dust in the atmosphere. Another important pollution source is derived from the dispersed PM emitted from the sea surface, generally referred to as sea spray. Sea spray is produced by the bubble-bursting processes or wind-induced wave breaking, resulting in a spray of particles in the size range from sub-micrometers up to a few micrometers [16]. Carbonaceous aerosol derived from wildfires is another natural source of aerosol constituents due to the burning of forests and other vegetation through natural processes [10]. In Mediterranean countries, fire emissions during summer have special relevance because the weather is dry and hot [17], and fire outbreaks are commonly fanned by strong winds. A further contribution to PM is given by volcanic emissions, which release a considerable variety of compounds, such as water vapor, ash, $\mathrm{CO}_{2}, \mathrm{SO}_{2}$, and $\mathrm{HCl}$ [18] through the summit of volcanic edifices as well as through fumarolic vents, which are generated by surface fractures usually occurring in the neighborhood of volcanoes [19]. Volcanic activity has not only a local impact on the troposphere but also a global influence since emissions may reach the stratosphere [20].

The lack of information about the contribution of volcanic activity to the aerosol in the atmosphere significantly restricts the assessments of environmental and human health risks, which are of considerable concern in the central sector of the Mediterranean Sea because of the presence of numerous active volcanoes including Etna and Stromboli and fumaroles such as those on the Volcano Island and in the area of Phlegraean Fields, or submarine fumaroles near Panarea Island. Several studies focused on the contribution of aerosol emissions from volcanic activities to the ambient air pollutants around the volcanoes or fumaroles using different approaches [21-24]. However, these works studied a single area at a time and provided for an on-land sampling of the aerosol, thereby assessing the impact near the sources. In previous work, our group dealt with the influence of volcanic sources on the atmospheric PM during a cruise campaign in the Mediterranean basin [25]; however, the local volcanic impact in the Mediterranean area has not been adequately investigated yet. In the effort to fill these observation gaps, the Institute of Atmospheric Pollution Research of the National Research Council (CNR-IIA) within the ongoing Med-Oceanor program [26] has started, since 2000, regular cruise measurement campaigns across the Mediterranean Sea. In this context, our work reports about the input from volcanoes and fumaroles to the levels and composition of atmospheric aerosols in the central Mediterranean Sea. We performed this study during the 2017 research cruise campaign covering the study of trace metals, ionic species, organic carbon (OC), and elemental carbon (EC). Aerosol particulate in its $\mathrm{PM}_{10}$ and $\mathrm{PM}_{2.5}$ fraction was collected and analyzed by different techniques for metal and ions determination. We merged the results of the chemical characterization with the PM investigation using scanning electron microscopy with energy-dispersive X-ray analysis (SEM/EDX) 
and strategies of data analysis including receptor modeling tools to identify the potential contribution of different sources to the PM in the central Mediterranean area.

\section{Studied Area and Measurement Scheme}

We performed aerosol sampling from 19 August to 4 September 2017 on-board of the research vessel "Minerva Uno" of the Italian National Research Council (CNR) during the oceanographic campaign Med-Oceanor 2017. Except for the last two days of the operation, the local weather conditions were characterized by low wind speed (between 0.3 and $13.5 \mathrm{~m} \mathrm{~s}^{-1}$ ) and by stable average daily values of temperature and pressure, ranging between 23.7 and $29.2^{\circ} \mathrm{C}$ and 1009 and $1019 \mathrm{hPa}$, respectively. The route involved 12 stops (Figure 1), each belonging to volcanic or fumarole areas. The volcanic area comprised Mount Etna, Stromboli Island, and Marsili Seamount, while the fumarole area comprised the Phlegraean Fields complex, Vulcano Island, Ischia Island, and Panarea submarine fumarole. To simplify the identification of the sampling zones, we labeled each stop using the name of the neighboring site.
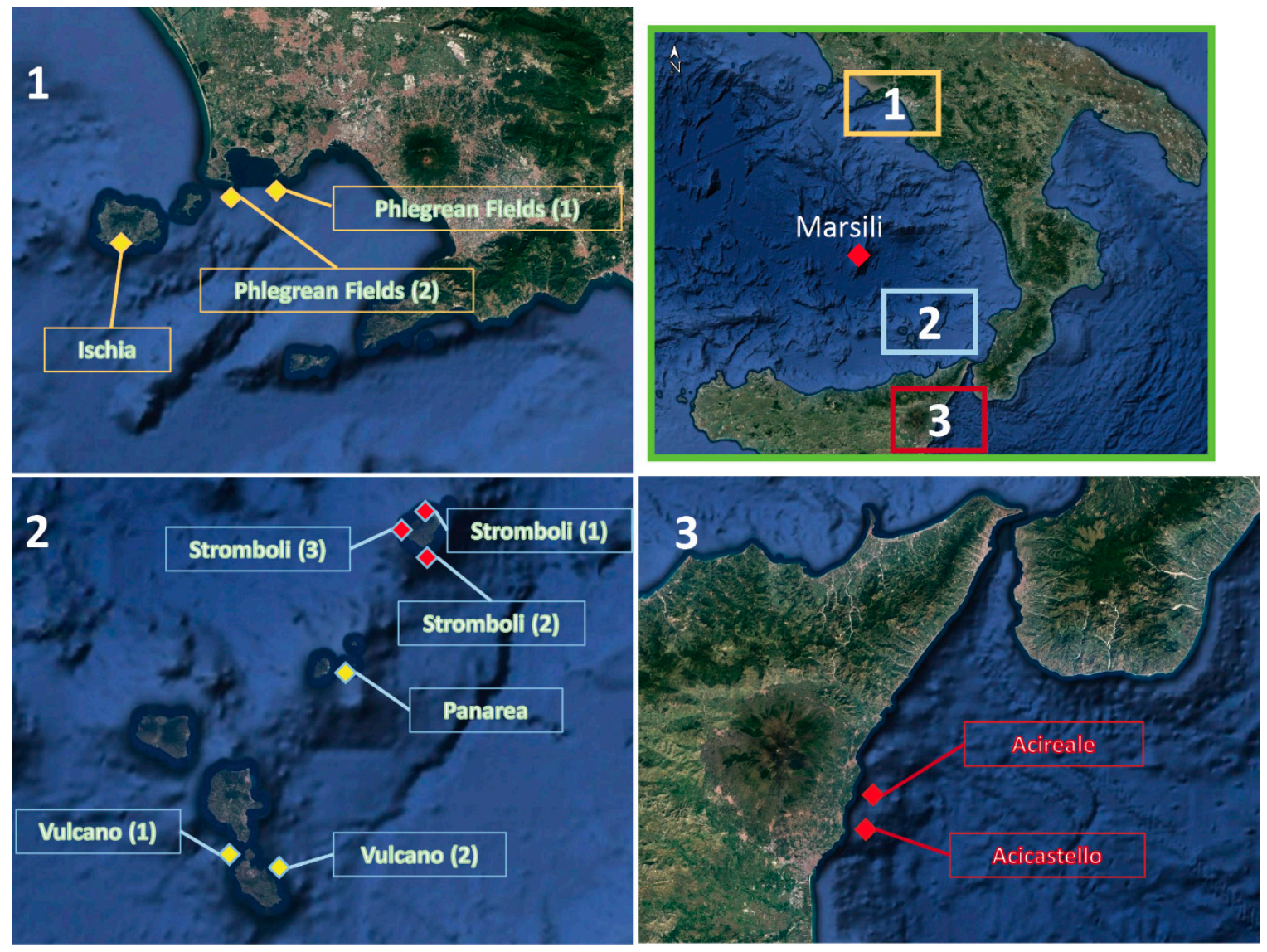

Figure 1. Map of sampling sites; red diamonds represent the volcanic sites while the yellow diamonds represent fumarolic sites: (1) Campania area; (2) Eolian archipelago; (3) Etnean area.

\subsection{The Mount Etna}

Mount Etna, one of the most active volcanoes in the world, covers an area of about $1250 \mathrm{~km}^{2}$ and reaches an altitude of about $3340 \mathrm{~m}$ a.s.l. $\left(37.754193^{\circ} \mathrm{N}, 14.978929^{\circ} \mathrm{E}\right)$ (Figure 1). It has been active during historical time, with frequent paroxysmal episodes separated by passive degassing periods. The edifice consists of a lower shield unit overlain by a stratovolcano [27] that is truncated at 2800-2900 m of altitude by the Ellittico caldera and Cratere del Piano, while the upper part of the volcano culminates with a large summit cone endowed with four active craters (Bocca Nuova, Voragine, Northeast, and Southeast Craters). The general atmospheric circulation in the Etnean area is 
predominantly westerly to northwesterly. According to these considerations, sampling sites in this zone were located in front of the Acireale and Acicastello coasts.

\subsection{Stromboli}

Stromboli is an island volcano belonging to the Eolian volcanic arc $\left(926 \mathrm{~m}\right.$ a.s.l; $38.7891^{\circ} \mathrm{N}$, $15.2131^{\circ} \mathrm{E}$ ) (Figure 1). It is an isolated volcano characterized by permanent activity and continuous gas emissions from potassium-rich basalt. Although Stromboli has a significant hydrothermal system [28], its magma also degasses directly into the atmosphere (i.e., at very high temperature, $>1000{ }^{\circ} \mathrm{C}$ ) from lava-filled vents. Such systems are often described as "open-conduit" volcanoes and can degas very large quantities of unerupted magma. Three different sampling sites around the island of Stromboli were monitored labeled as Stromboli (1), Stromboli (2), and Stromboli (3).

\subsection{Marsili}

Marsili Seamount is about $60 \mathrm{~km}$ long and $20 \mathrm{~km}$ wide, rising about $3000 \mathrm{~m}$ from the seafloor at over $3500 \mathrm{~m}$ water depth $\left(39.236276^{\circ} \mathrm{N}, 14.369875^{\circ} \mathrm{E}\right.$ ) (Figure 1). The possible existence of a very large underwater explosive volcano, together with some encouraging clues that point to Marsili as an important and potential long-lasting-renewable energy resource [29], has reinforced research and exploitation efforts in this area. The existence of an active magmatic chamber at about $2.5 \mathrm{~km}$ below the summit was proposed on the basis of petrologic studies of basalts [30], and it is compatible with gravimetric and magnetic data modeling [31], as well as geochemical observations on the summit [32]. We monitored this area by a sampling stop above the crater of the volcano.

\subsection{Phlegraean Fields}

Solfatara, a crater located within the Phlegraean Fields (458 m a.s.l.; $40.8271^{\circ} \mathrm{N}, 14.1391^{\circ} \mathrm{E}$ ), a quaternary volcanic complex near Naples (Figure 1), is renowned for its vigorous, low-temperature degassing. Indeed, the term Solfatara is applied to many similar manifestations found in other volcanic regions of the world. The hottest fumaroles at Solfatara reach temperatures of $140-160^{\circ} \mathrm{C}$. Previous studies indicate that gas emissions are dominated by $\mathrm{H}_{2} \mathrm{O}$, followed by $\mathrm{CO}_{2}$ and $\mathrm{H}_{2} \mathrm{~S}$ [33]. In this area, sampling was performed at two different sites (labeled as Phlegraean Fields (1) and Phlegraean Fields (2)) along the direction of the inland Solfatara crater at a distance of about $1 \mathrm{~km}$.

\subsection{Vulcano}

The volcanic island of Vulcano is the southernmost of the seven islands forming the Eolian Archipelago in the Tyrrhenian Sea north of Sicily (500 m a.s.1.; $38.4041^{\circ} \mathrm{N}, 14.9621^{\circ} \mathrm{E}$ ). Since the last eruption of Vulcano in 1888-1890, a vigorous fumarole field has been developed in the summit crater, known as La Fossa. Numerous geochemical investigations have focused on Vulcano, especially since increases in gas fluxes and temperatures were observed in the 1970s. Similarly to the Solfatara site, Vulcano does not have magma on the surface but its fumaroles reach high temperatures, well over $300^{\circ} \mathrm{C}$ at some vents. In Vulcano, we sampled at two sites labeled as Vulcano (1) and Vulcano (2) (Figure 1).

\subsection{Ischia}

Ischia $\left(40.7352^{\circ} \mathrm{N}, 13.8517^{\circ} \mathrm{E}\right)$ is the westernmost active volcanic complex of the Campania area and belongs to the Phlegraean volcanic district, which also includes Phlegraean Fields (Figure 1). In Ischia, the last eruption took place in 1301, and since that time, several earthquakes affected the island. Thermal manifestations characterize Ischia including thermal waters and fumaroles, which have been well known since Roman times and are the main economic resource of the island at present. The fumarolic activity is mainly concentrated along the faults affecting Mt. Epomeo (789 $\mathrm{m}$ a.s.l.), a resurgent block in the central part of the island. In this area, we performed aerosol sampling in a site labeled Ischia (Figure 1). 


\subsection{Panarea}

Panarea Island (Eolian Archipelago) lies in the western sector of a submarine $120 \mathrm{~m}$ deep platform constituting the $56 \mathrm{~km}^{2}$ wide summit of a $2000 \mathrm{~m}$ high seamount $\left(38.6369^{\circ} \mathrm{N}, 15.1026^{\circ} \mathrm{E}\right)$ (Figure 1). Close to Panarea, a group of islets (Dattilo, Panarelli, Lisca Bianca, Bottaro, Lisca Nera, and Le Formiche) forms an archipelago that surrounds a submerged fumarolic area, which is characterized by relatively shallow depth $(<35 \mathrm{~m})$, hosting gas, and thermal water discharges. Geochemical studies of fluids from the submarine fumarolic field of this area started in the early 1990s [34], and were then fostered by the gas burst event that occurred on 3 November 2002 [35]. One sampling site, labeled Panarea, was selected offshore as a monitoring point.

\section{Experiments}

\subsection{Sampling and Laboratory Analysis}

The aerosol sampling equipment was fixed on the deck at about $30 \mathrm{~m}$ above the sea level on the front of the ship to avoid contamination from the ship exhaust. Daily 24-h ambient $\mathrm{PM}_{10}$ and $\mathrm{PM}_{2.5}$ samples were collected on quartz fiber filters of $47 \mathrm{~mm}$ in diameter (2500 QAT-UP, Pallflex ${ }^{\circledR}$, Putnam, CT, USA) using a low volume sampler Echo PM (, TCR Tecora, Cogliate, Italy) operating at a flow of $2.3 \mathrm{~m}^{3} \mathrm{~h}^{-1}$. In accordance with the European Standard UNI EN 12341:2014, filters were conditioned for $48 \mathrm{~h}$ before and after sampling, at a temperature and relative humidity of $20 \pm 1{ }^{\circ} \mathrm{C}$ and $50 \pm 5 \%$, respectively. The conditioned filters were weighed using a microbalance Crystal Micro (Gibertini, Novate, Italy) in order to determine the mass of both the PM fractions by standard gravimetric procedures, whereupon the filters were analyzed for the determination of the chemical composition. The analysis of the carbonaceous fraction of aerosol $(\mathrm{TC}=\mathrm{OC}+\mathrm{EC})$ was performed on a $1 \mathrm{~cm}^{2}$ portion of each filter by a thermal-optical transmission (TOT) technique using an OC/EC Analyzer (Sunset Laboratory Company, Tigard, OR, USA) and following the EUSAAR-II temperature protocol [36]. Briefly, the small punch of the filter was subjected to two stepwise heating cycles, which favored the volatilization and combustion processes of the carbonaceous material. The evolved carbon was converted to methane and subsequently detected by a flame ionization detector (FID) during both temperature cycles, which occurred in a non-oxidizing and oxidizing atmosphere, respectively. Laser light of $670 \mathrm{~nm}$ continuously monitored the transmittance through the sample filter in order to correct for pyrolyzed OC conversion to EC.

Chemical characterization of PM samples was performed by Inductively Coupled Plasma Atomic Emission Spectrometry (iCAP 6500, Thermo Scientific) for major elements (Al, Ca, Na, Mg, K, Fe, P, S) and Inductively Coupled Plasma Mass Spectrometry (iCAP-RQ, Thermo Scientific) for trace elements ( $\mathrm{Li}, \mathrm{Ti}, \mathrm{V}, \mathrm{Cr}, \mathrm{Mn}, \mathrm{Co}, \mathrm{Ni}, \mathrm{Cu}, \mathrm{Zn}, \mathrm{As}, \mathrm{Se}, \mathrm{Rb}, \mathrm{Sr}, \mathrm{Cd}, \mathrm{Sn}, \mathrm{Sb}, \mathrm{Ba}, \mathrm{La}, \mathrm{Ce}, \mathrm{Hf}, \mathrm{Pb}, \mathrm{Bi}, \mathrm{Th}, \mathrm{U}$ ). Half of each filter was acid digested with a mixture of $\mathrm{HF}: \mathrm{HNO}_{3}: \mathrm{HClO}_{4}(2.5: 1.25: 1.25 \mathrm{~mL})$ in a Teflon reactor for $9 \mathrm{~h}$ at a temperature of $90{ }^{\circ} \mathrm{C}$. Each digested sample was driven to dryness, re-dissolved with $1.25 \mathrm{~mL} \mathrm{HNO}_{3}$, and made up to a final volume of $25 \mathrm{~mL}$ with ultrapure water [37]. Relative analytical errors were estimated using a small amount $(15 \mathrm{mg}$ ) of the NIST-1633b (fly ash) reference material loaded on a $\frac{1}{4}$ quartz fiber filter. Individual uncertainties were calculated taking into account the analytical uncertainty and the standard deviations of the element concentrations in the blank filters [38]. Since the portions of the $\mathrm{PM}_{2.5}$ filters for the sites Acireale, Panarea, and Vulcano (2) were contaminated during the storage, we discarded these samples before the chemical analysis for major and trace elements. For the quantification of ammonium by ion-selective electrode (Orion 9512HPBNWP of Thermo Scientific) and soluble ions, such as sulfate, nitrite, nitrate, fluoride, bromide, chloride, and phosphate, by ion chromatography (Aquion, Thermo Scientific), the leftover filter was water leached in $20 \mathrm{~mL}$ sealed PVC bottles (for $14 \mathrm{~h}$ at $60^{\circ} \mathrm{C}$ ), preceded by an ultrasonic bath of $15 \mathrm{~min}$. Sulfur dioxide $\left(\mathrm{SO}_{2}\right)$ measurements were performed using a Teledyne UV Fluorescence $\mathrm{SO}_{2}$ Analyzer (API Model 100EU) with a sampling flow rate of $0.6 \mathrm{~L} \mathrm{~min}^{-1}$ and a time resolution of $1 \mathrm{~min}$. A particle sampling cassette system (SKC, inlet diameter $1 / 8$ inch), which housed transmission electron microscope (TEM) 
grids attached to filter support pads ( $25 \mathrm{~mm}$ in diameter), was used to collect particles for offline characterization following a similar procedure described elsewhere [39,40]. The system utilized an SKC Leland pump that was operated at a flow of $5 \mathrm{~L} \mathrm{~min}^{-1}$ for a duration of $4 \mathrm{~h}$. The grids (Agar Scientific Quantifoil $200 \mathrm{Mesh} \mathrm{Au}$ ) were analyzed offline for morphological and physicochemical particle characterization using a Field Emission Scanning Electron Microscope (JEDL J-7100) coupled with an energy-dispersive X-ray spectroscopy (EDS; retroscattered electron detector) spectrometer.

\subsection{Chemical Mass Closure}

For the purpose of mass closure, the chemical components were grouped as sea salt (ss), mineral dust, organic matter and elemental carbon $(\mathrm{OM}+\mathrm{EC})$, secondary inorganic aerosols (SIA), and trace elements. Each of these components can originate from a variety of sources, some of which play a significant role in their production.

As regards to the sea salt component, six major ions represent more than $99 \%$ of the mass of salts

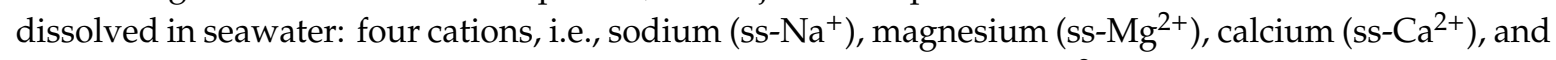
potassium $\left(\mathrm{ss}-\mathrm{K}^{+}\right)$, and two anions, chloride $\left(\mathrm{ss}^{-} \mathrm{Cl}^{-}\right)$and sulfate $\left(\mathrm{ss}^{-} \mathrm{SO}_{4}{ }^{2-}\right)$. Thus, sea salt concentration was calculated from Equation (1) [41].

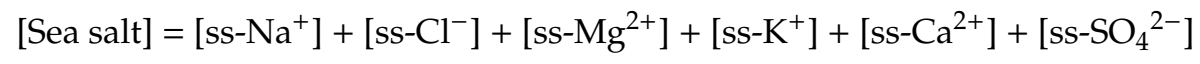

To calculate the sea salt sodium $\left[\mathrm{ss}-\mathrm{Na}^{+}\right]$, the value of non-sea salt sodium (nss-Na) was subtracted from the total $\mathrm{Na}$ value $\left(\left[\mathrm{ss}-\mathrm{Na}^{+}\right]=[\mathrm{Na}]-[\mathrm{nss}-\mathrm{Na}]\right)$ resulting from the chemical analysis. The [nss-Na] value was obtained from the $\mathrm{Al}$ concentration multiplied by the $\mathrm{Na} / \mathrm{Al}$ ratio in the average crustal composition [42]. Based on the seawater composition, the sea salt sulfate [ $\mathrm{ss}^{-\mathrm{SO}_{4}}{ }^{2-}$ ] is calculated as 0.2509 times $\left[\mathrm{ss}-\mathrm{Na}^{+}\right]$, sea salt calcium $\left[\mathrm{ss}-\mathrm{Ca}^{2+}\right]$ calculated as 0.038 times $\left[\mathrm{ss}-\mathrm{Na}^{+}\right]$, sea salt potassium $\left[\mathrm{ss}-\mathrm{K}^{+}\right]$as 0.037 times $\left[\mathrm{ss}-\mathrm{Na}^{+}\right]$, and sea salt magnesium $\left[\mathrm{ss}-\mathrm{Mg}^{2+}\right.$ ] calculated as 0.1187 times $\left[\mathrm{ss}-\mathrm{Na}^{+}\right]$. For $\left[\mathrm{ss}-\mathrm{Cl}^{-}\right]$, although the unavoidable reaction of $\mathrm{NaCl}$ particles with the atmospheric traces of acidic species including $\mathrm{H}_{2} \mathrm{SO}_{4}$ and $\mathrm{HNO}_{3}$ can lead to the volatilization of $\mathrm{Cl}^{-}$as $\mathrm{HCl}$ [37]; thus, determining the underestimation of SS component, it can be reasonably assumed that $\left[\mathrm{ss}^{-} \mathrm{Cl}^{-}\right]$is approximately equal to the total $\left[\mathrm{Cl}^{-}\right]$in a marine environment. As a consequence, the $\left[\mathrm{Cl}^{-}\right]$was used in the estimation of [sea salt].

Mineral dust is generated from the suspension of the minerals constituting the soil and can be expressed as the sum of the most common oxide forms [37]. In our study, dust content was estimated using Equation (2) as the sum of the concentrations of $\mathrm{Al}, \mathrm{Ca}, \mathrm{Mg}, \mathrm{K}, \mathrm{Fe}, \mathrm{P}$, and Ti, each multiplied by factors to convert them to their common oxides and $\mathrm{SiO}_{2}$, calculated multiplying $\left[\mathrm{Al}_{2} \mathrm{O}_{3}\right]$ by 2.5 .

$$
[\text { Dust }]=\left[\mathrm{Al}_{2} \mathrm{O}_{3}\right]+[\mathrm{CaO}]+[\mathrm{MgO}]+\left[\mathrm{K}_{2} \mathrm{O}\right]+\left[\mathrm{Fe}_{2} \mathrm{O}_{3}\right]+\left[\mathrm{P}_{2} \mathrm{O}_{5}\right]+\left[\mathrm{TiO}_{2}\right]+\left[\mathrm{SiO}_{2}\right]
$$

EC was obtained from thermal-optical analysis (as described in Section 3.1), while the OM contribution, which accounts for the unmeasured $\mathrm{H}, \mathrm{O}, \mathrm{N}$, and $\mathrm{S}$ in organic compounds, was calculated according to Equation (3), which considers also the influence of the water-soluble organic carbon (WSOC) on the mass, that for non-urban aerosol is about $40 \%$ of the OC mass.

$$
\mathrm{OM}=f \times \mathrm{OC}
$$

In this equation, OC was experimentally determined by thermal-optical analysis while the $f$ multiplier is a coefficient that is not site- or time-specific. Depending on the extent of OM oxidation and secondary organic aerosol (SOA) formation, values for $f$ vary from 1.2 for fresh aerosol in urban areas [43] to 2.6 for aged aerosol [44-46]. The conversion factor $f$ is usually taken in the range from 1.4 for urban aerosols to 1.8 for remote aerosols. Turpin et al. revisited these conversion factors and proposed values of $1.6 \pm 0.2$ and $2.1 \pm 0.2$ for urban and non-urban aerosols, respectively [46]. Based on the previous consideration, the $f$ value was set at 2.1 for the calculations in our work. 
The secondary inorganic aerosol was calculated as the sum of non-sea-salt $\left[\mathrm{SO}_{4}{ }^{2-}\right],\left[\mathrm{NO}_{3}{ }^{-}\right]$, and $\left[\mathrm{NH}_{4}{ }^{+}\right]$. Sulfate, in turn, is made by a component in both sea salt and non-sea-salt $\mathrm{SO}_{4}{ }^{2-}$ ( $\mathrm{ss}^{-\mathrm{SO}_{4}}{ }^{2-}$ and nss- $\mathrm{SO}_{4}{ }^{2-}$ ) derived from the atmosphere. With our investigation being in the marine environment, the non-sea-salt sulfate was calculated as $\left[\mathrm{nss}-\mathrm{SO}_{4}{ }^{2-}\right]=\left[\mathrm{SO}_{4}{ }^{2-}\right]-0.25094\left[\mathrm{Na}^{+}\right]$, based on $\left[\mathrm{SO}_{4}{ }^{2-}\right] /\left[\mathrm{Na}^{+}\right]$ molar ratio in seawater $[37,47,48]$.

The last contribution to the PM mass closure, which derives from trace elements, was obtained as the sum of the trace element concentrations. The sum of all the above determinations accounted for $81.9 \%$ and $83.0 \%$ of the $\mathrm{PM}_{10}$ and $\mathrm{PM}_{2.5}$ average mass, respectively. The remaining undetermined mass can be attributed to the structural and adsorbed water that is not removed during the sample conditioning.

\subsection{Data Analysis and Receptor Modeling}

In order to characterize the daily atmospheric scenarios influencing PM levels, we used several complementary tools to interpret the different sources of air masses in the studied area. We calculated air mass backward trajectories using the US NOAA HYSPLIT model [49] with GDAS meteorological data. The occurrence of African dust outbreaks was also confirmed by the same tools coupled with the information of the NAAPS aerosol maps from the Naval Research Laboratory, USA (NRL) (Navy Aerosol Analysis and Prediction System) and the BSC-DREAM dust maps [50]. Enrichment factors (EFs) and factor analysis (FA) were used for source identification and apportionment of particulate air pollutants at receptor sites, whereas linear discriminant analysis (LDA) was exploited to perform supervised pattern recognition analysis using the chemical descriptors of PM samples according to their volcanic (Vo) or solfatara (So) origin.

The calculation of EFs is useful to rank the enrichment degree of an element compared to a known source; in this case, the $\mathrm{Al}$ concentration was considered as the basis for comparison. EF is defined as the ratio between the concentration of an element $i\left(E_{\text {sample }}^{i}\right)$ and that of a reference element $\left(A l_{\text {sample }}\right)$ in the sample, normalized to the same ratio in the Earth's crust [42]. Specifically, for each element $i$, the $E F_{i}$ was calculated according to Equation (4).

$$
E F_{i}=\frac{E_{\text {sample }}^{i} / A l_{\text {sample }}}{E_{\text {volc }}^{i} / A l_{\text {volc }}}
$$

where volc refers to the volcanic rocks (basalt and lava in this case), which were considered as the geogenic source. In our study, the $E F_{i}$ in Etna and Stromboli plumes was calculated using the aluminum as normalizing element, while the average Etnean lava [23] and the Stromboli basalt [51] were used, respectively, as reference material.

Factor analysis (FA) is widely used to determine the number of independent sources that contribute to the system and elemental source profiles. The association of the factors with the source type is possible by comparing the elements with the highest loading within each component with the elements commonly emitted by recognized source types. In our work, the whole dataset was subjected to factor analysis using the software Statistica (StatSoft,) and Varimax rotation was applied to assure the maximum differentiation between the factors. The number of potential factors was limited to eight, but only six factors were obtained.

Linear discriminant analysis (LDA) is a chemometric tool that defines a set of delimiters that divide the multivariate space of the samples into as many subspaces as the number of the classes. Discriminant functions are computed as a linear combination of variables that maximizes the ratio of variance between categories to variance within categories. An essential restriction in the application of LDA concerns the ratio between the number of samples and the number of variables. Indeed, it is recommended that the number of samples is at least three times the number of variables to obtain a robust model. Therefore, in our study, a stepwise approach (S-LDA) was used for the selection of the variables with a major discriminant power. The S-LDA was used to differentiate between the PM samples collected in the volcanic (Vo) and solfatara (So) sites on the basis of their chemical composition. 
The dataset was slightly different from that used for FA because, for LDA, the variables that can be associated exclusively with an anthropogenic origin (Mo, EC, and OC) were not included in the dataset. Furthermore, the Acireale sample was excluded because it was affected by the Saharan Dust Outbreak (SDO), as pointed out from chemical characterization (see Section 4.2). Partial Wilks' $\lambda$ values were used to figure out the variables that actually contributed to differentiation, i.e., the closer to zero its value is, the higher is the discriminatory importance of this variable in the model.

\section{Results and Discussions}

\subsection{Meteorological Conditions}

The trends of temperature, pressure, and wind speed recorded during the cruise by the on-board instrumentation are illustrated in Figure S1. During all the sampling days, the absence of precipitations, low wind intensity (with the maximum speed being $13.5 \mathrm{~m} \mathrm{~s}^{-1}$ ), and a mean atmospheric temperature of $26.1^{\circ} \mathrm{C}$ characterized the local weather. Information on wind direction and intensity are reported for each sampling site by the wind rose diagrams (Figure S2). Based on the average daily wind speed values and the Beaufort wind scale, we encountered light breeze for eight sampling days and gentle breeze for four sampling days. The atmospheric pressure exhibited the lowest average values and the largest variability between 1 September and 4 September 2017, with a minimum on 2 September, associated with episodes of strong wind and rough sea that forced us to stop in the Harbor of Lipari Island to shelter from the bad weather. The NCEP/NCAR Reanalysis [52] tool shows the composite means and anomalies of the sea level pressure over the Mediterranean basin during the campaign, supporting the worsening of the weather (Figure S3). Indeed, while in August the expansion of the Azores Anticyclone characterized the synoptic conditions in line with seasonal climatology in the Mediterranean, on 2 September the anticyclonic system was confined over the Atlantic Ocean and North of Europe, thus favoring the development of low-pressure systems across Eastern Europe and the Mediterranean basin.

\subsection{Percentage Chemical Composition of PM}

The mass concentration values for $\mathrm{PM}_{10}$ and $\mathrm{PM}_{2.5}$ recorded during the campaign ranged between 12.3 and $30.7 \mu \mathrm{g} \mathrm{m}^{-3}$ and 9.4 and $18.3 \mu \mathrm{g} \mathrm{m}^{-3}$, respectively (Figure 2). The $\mathrm{PM}_{10}$ concentration in each site was lower than the daily limit value of $50 \mathrm{\mu g} \mathrm{m}^{-3}$, as set by the Directive 2015/1480/EC on ambient air quality. It is known that natural episodes, although they occur less frequently than anthropic ones, can influence air quality especially in the surroundings of marine areas and zones with tectonic activity [2]. The percentage chemical composition of the PM samples collected during the cruise is summed up in Table S1 and illustrated in Figure 2.

For the $\mathrm{PM}_{10}$, the main components were carbonaceous $(\mathrm{OM}+\mathrm{EC})$ and mineral dust aerosols, with average contributions of $27.2 \%$ and $26.6 \%$, respectively. The dust load reached a peak of $44.7 \%$ at Acireale, owing to a North African dust outbreak as confirmed by NAAPS, BSC-DREAM, and backward trajectories maps presented in Figure S4. The carbonaceous fraction was above the $20 \%$ for the whole campaign with the maximum amount of $38.3 \%$, which was found in Phlegraean Fields (1) and may be due to the interception of air masses moving from the urbanized coast near the sampling area, which is characterized by high vehicular traffic. This assumption is supported by the levels of EC $\left(0.95 \mu \mathrm{g} \mathrm{m}^{-3}\right)$ and OC $\left(3.64 \mu \mathrm{g} \mathrm{m}^{-3}\right)$, which were found at their highest concentrations at this stop. The SIA component had an average mass contribution to $\mathrm{PM}_{10}$ of $19.9 \%$ with a maximum of $26.3 \%$ at Stromboli (2). Trace elements and sea salt contributed marginally to the mass, with tracers that accounted for less than $1 \%$ and sea salt for about $10 \%$. We detected the maximum value of trace elements in the Ischia sample, where it represented $1.6 \%$ of $\mathrm{PM}_{10}$ mass. The relatively low contribution of sea salt compared to what can be expected in a marine atmosphere may be attributed to the stable weather encountered for most of the campaign, except for rough sea and strong blowing wind arose at Vulcano (2), where we recorded a higher percentage of the sea salt component $(23.7 \%)$. 
Indeed, the occurrence of substantial sea spray production needs wind with an intensity and duration strong enough to allow its formation [53]. For $\mathrm{PM}_{2.5}$, the component prevailing on average was the carbonaceous aerosols (35.3\%), which reached the maximum value in the Phlegraean Fields (1) (56.2\%), thus reinforcing the preceding hypothesis involving the vehicular traffic contribution in this area. For SIA, the average loading reached $24.7 \%$, thereby showing that its components (i.e., $\mathrm{SO}_{4}{ }^{2-}, \mathrm{NH}_{4}{ }^{+}$, and $\mathrm{NO}_{3}{ }^{-}$) prevailed in the $\mathrm{PM}_{2.5}[37,54]$. In both fractions, the maximum value of SIA was obtained in the sample Stromboli (2), where the upwind sampling (wind roses presented in Figure S2) led to a better interception of volcanic emissions characterized by high $\mathrm{SO}_{2}$ values, which affected the increase of $\mathrm{SO}_{4}{ }^{2-}$ concentration because of its reaction with the atmospheric water and the condensation on particles. In support of this, as showed in the time series plots of $\mathrm{SO}_{2}$ (Figure S5), we recorded a peak of $\mathrm{SO}_{2}$ at this site, which lasted for about $5 \mathrm{~h}$ during that sampling day. As expected, the average mineral dust contribution was smaller in $\mathrm{PM}_{2.5}$ than in $\mathrm{PM}_{10}(17.6 \%$ and $25.6 \%$, respectively), with the highest value reached in Acireale because of the SDO (Figure S4). Average sea salt contribution to $\mathrm{PM}_{2.5}$ was $4.3 \%$, with the maximum value in Marsili (10.7\%), while the trace elements were averagely higher in $\mathrm{PM}_{2.5}$ (1.2\%) than $\mathrm{PM}_{10}(0.9 \%)$, with the maximum values recorded in Phlegraean Fields (1) and Phlegraean Fields (2) (1.4\% and $1.6 \%$, respectively).

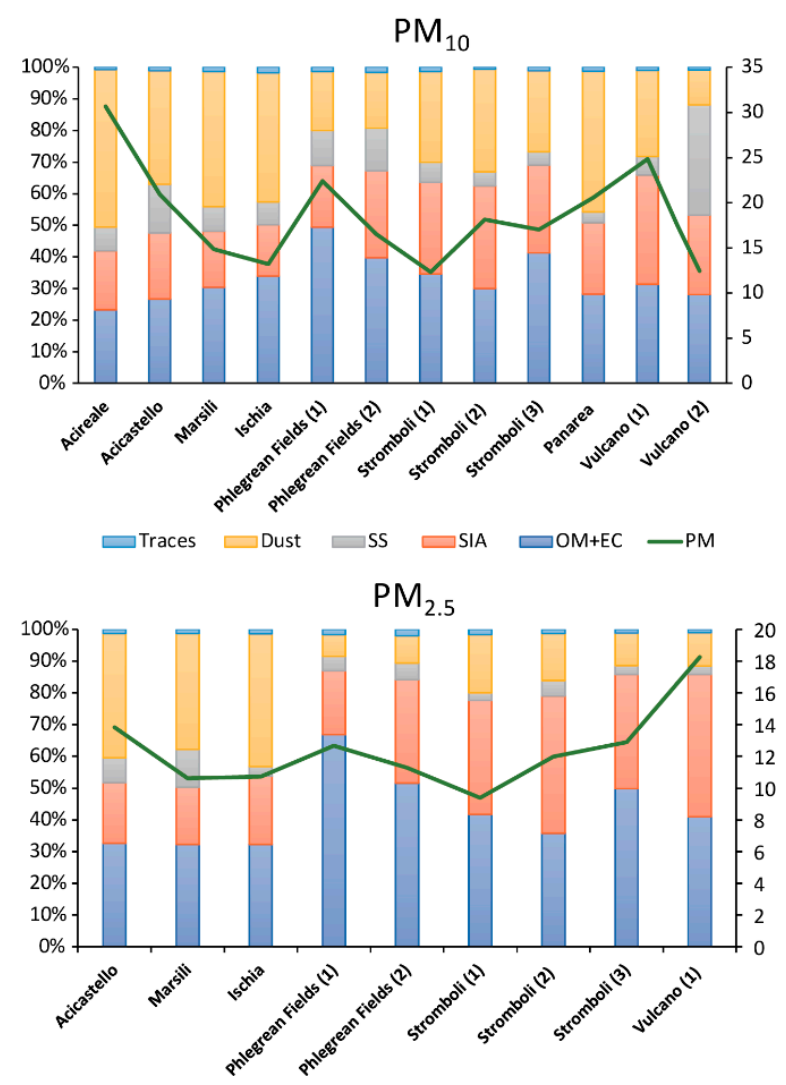

Figure 2. Chemical composition (as a percentage) and mass concentration of particles (expressed in $\mu \mathrm{g}$ $\mathrm{m}^{-3}$ ) of the $\mathrm{PM}_{10}$ and $\mathrm{PM}_{2.5}$ samples.

\subsection{Volcanic Areas}

There are several studies reporting the relevance of volcanic emissions as sources of metal-bearing gases and PM into the atmosphere [51,54-57]. A previous study revealed that volcanogenic trace metals are injected in the atmosphere as volatile elements, emitted from the silicate melt during magma degassing, and later dispersed in atmospheric plumes as sub-micron sized volcanic aerosols and low volatile (refractory or lithophile) elements, transported via coarse volcanic ash fragments [23]. The volcanic area monitored during the campaign, as previously discussed, included Etna and 
Stromboli, which are sub-aerial volcanoes with a significant part of their structure under the sea, while the Marsili Seamount is submerged and its activity is still open to debate. In this regard, at the Marsili site, we observed low values for each component constitutive of PM, except for sea salt in $\mathrm{PM}_{2.5}$, which reached the highest percentage in this site $(10.7 \%)$ due to the low contributions of the other pollution sources because the sampling site was over $100 \mathrm{~km}$ from inland.

In our study, we used $\mathrm{Al}, \mathrm{Ca}$, and $\mathrm{Fe}$, as tracers of crustal emissions to find out the volcanic-derived contribution to PM by comparing their average concentrations in the samples with the literature reference data. In particular, for information about the chemical composition of Etna's and Stromboli's lava and ash, we referred to the work of Calabrese et al. [23] and Allard et al. [51], respectively, while for the data on the chemical composition of Sahara and Sahel dust, we used the values provided by Moreno et al. [58]. The relative proportions of $\mathrm{Al} / \mathrm{Ca} / \mathrm{Fe}$ measured at Acireale and Acicastello are similar to the typical Etna's values in both ash and lava, confirming that samples, though collected at a considerable distance from the source (almost $40 \mathrm{~km}$ ), are affected by the volcanic plume that spreads throughout the area (Figure 3a). The value of Acireale shown in Figure 3a is shifted toward the values of Sahara and Sahel, thus confirming the intrusion of air masses coming from the African desert region during the sampling. The ternary plot for the samples collected around Stromboli shows a similar composition with the reference values of magma reported in the literature [51]. In particular, the samples identified as Stromboli (2) and Stromboli (3) have a greater similitude with the composition of the basaltic lava, whereas the composition for the sample Stromboli (1) is closer to that of the volcanic ash (Figure 3b).
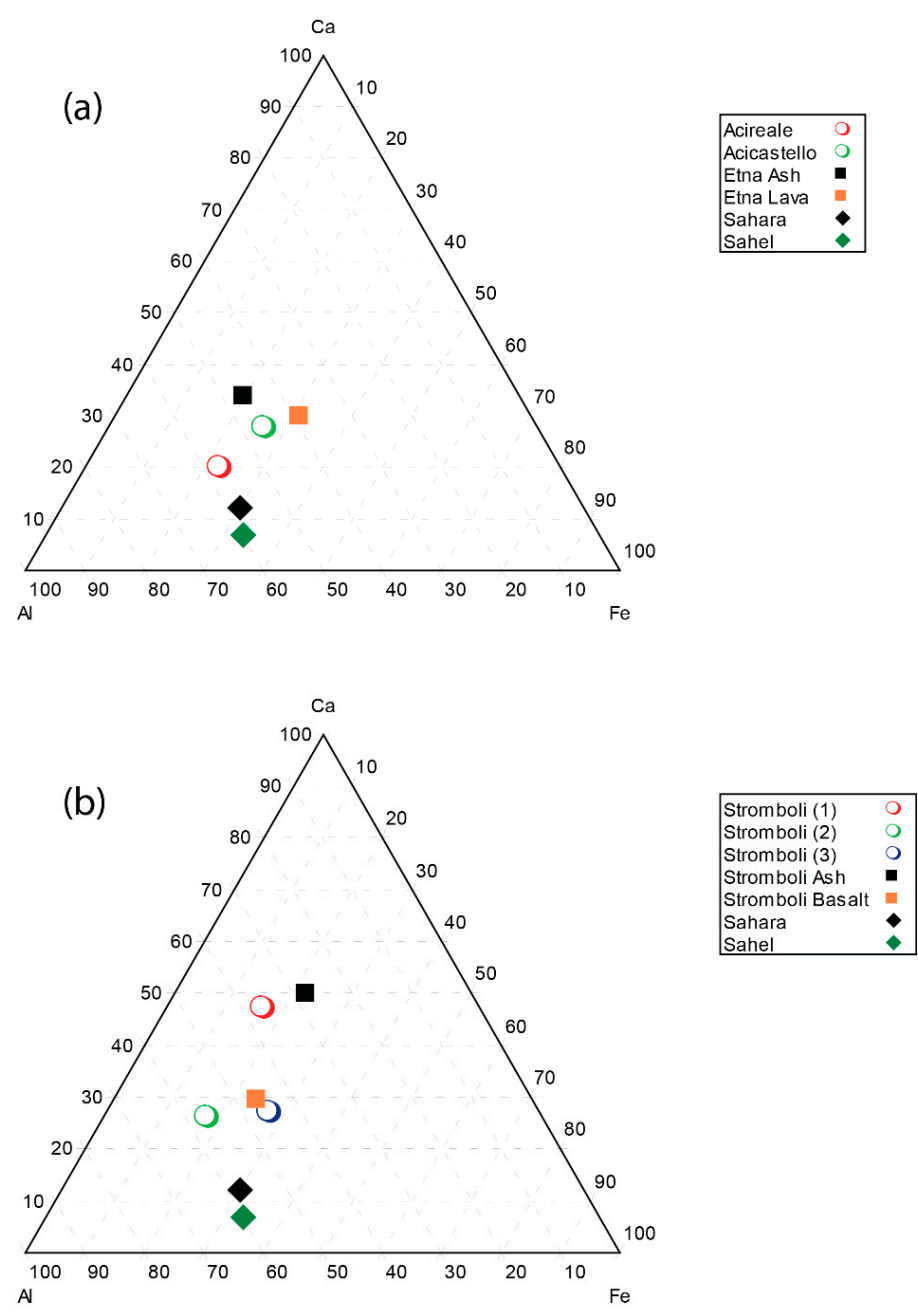

Figure 3. Ternary plot for Etna's sampling area (a) and Stromboli's sampling area (b). 
Besides, the load of the volcanic plume aerosol in the sampled PM was investigated through the calculation of the enrichment factors, which is a useful tool to highlight the enrichment or depletion degree of an element in a geochemical medium relative to reference material. Although the use of EFs could hide some flaws, such as the variable composition of the reference material, or inadequate choice of the element used to normalize the data [59], it provides a first-order insight on the geogenic or anthropogenic origin of the elements. Based on the results of the ternary plot, we calculated the EFs for Acicastello and Stromboli (3), which are the samples identified as those with the greatest volcanic contribution. EFs were computed according to Equation (4) using $\mathrm{Al}$ as a reference element because it is a low volatile element at magmatic conditions, and also one of the most immobile elements during the weathering of basalts [60]. Values of EF close to one indicate that there is no enrichment occurring for an element in sampled PM compared to the expected abundance in volcanic basalt. EFs far exceeding one characterize volatile elements enriched in the plume because of their affinity for the magmatic vapor phase or might indicate an anthropogenic origin. Despite some peculiarities, the EFs for the samples Stromboli (3) and Acicastello are overall consistent. The EFs illustrated in Figure S6 suggest that, for both volcanoes, the elements can be grouped into four categories according to the EF values. The strongly enriched elements in PM (EFs > 100) were those with a marked volcanic-volatile character or anthropogenic origin species (i.e., $\mathrm{Sn}, \mathrm{Sb}, \mathrm{Cr}$, Se). The enriched elements such as $\mathrm{Ni}, \mathrm{Zn}, \mathrm{U}, \mathrm{As}, \mathrm{Pb}$, and $\mathrm{Tl}$ were those with EFs ranging from 10 to 100 , while the elements with $\mathrm{EF} \approx 1-10$ such as $\mathrm{Cu}, \mathrm{K}$, $\mathrm{Ba}, \mathrm{Rb}$, and some rare earth elements including $\mathrm{Th}, \mathrm{Sm}, \mathrm{Ce}$, and La were associated with a geogenic origin. The elements with $\mathrm{EFs}<1$, such as $\mathrm{Co}, \mathrm{Ti}, \mathrm{Mg}$, and $\mathrm{Sr}$, can be considered depleted elements compared to geogenic elements and indicate a local geological reduction relative to volcanic rocks. The volatile-anthropogenic species, including $\mathrm{Sb}, \mathrm{Cr}$, and $\mathrm{Sn}$, were enriched by two to three orders of magnitude in the PM of both volcanic sites. Furthermore, another enriched element was Ni which may be related to anthropogenic sources and is commonly associated, together with $\mathrm{V}$, to shipping emissions. Among the enriched elements, the presence of Tl only in the Etna sample pointed out the volcanic contribution to PM [23].

\subsection{Fumarole Areas}

Sulfur dioxide is a valuable tracer of degassing processes by geothermal sources such as fumaroles and volcanoes. In this work, we averaged on a daily basis the $1 \mathrm{~min}$ recorded data obtained from the $\mathrm{SO}_{2}$ analyzer (Figure S5) in order to allow a direct comparison with the nss-SO ${ }_{4}{ }^{2-}$ concentration values, as obtained from the analysis of the $24 \mathrm{~h}$ PM samples. As a result, we found a strong correlation in both $\mathrm{PM}$ fractions between the nss- $\mathrm{SO}_{4}{ }^{2-}$ levels in the fumarole area with the corresponding average daily levels of $\mathrm{SO}_{2}$ concentration, thus supporting the hypothesis that local $\mathrm{SO}_{2}$ emissions are important for the formation of nss- $\mathrm{SO}_{4}{ }^{2-}$ as reported in Section 4.2 about the SIA. In particular, Figures S7a and S5b illustrate the correlation between the concentrations of $\mathrm{SO}_{2}$ and nss- $\mathrm{SO}_{4}{ }^{2-}$ for each site in both fractions, with $\mathrm{R}^{2}=0.76$ for $\mathrm{PM}_{10}$ and $\mathrm{R}^{2}=0.74$ for $\mathrm{PM}_{2.5}$. This correlation is further improved by neglecting the Vulcano (2) sample (Figure $S 7 c, d$ ), thus achieving $R^{2}=0.95$ and $R^{2}=0.92$ for $P_{2.5}$ and $\mathrm{PM}_{10}$, respectively. The observed increase in correlation may be due to the different atmospheric conditions that occurred during the sampling in Vulcano (2) when the rough sea and wind gusting may have affected the nss- $\mathrm{SO}_{4}{ }^{2-}$ by favoring trapping of $\mathrm{SO}_{2}$ with $\mathrm{NaCl}$ reactions. This result is confirmed by the concentration of nss-SO ${ }_{4}{ }^{2-}$ and $\mathrm{SO}_{2}$ reported in Figure 4, showing the larger gap between these two chemical species in Vulcano (2) compared to Vulcano (1). 

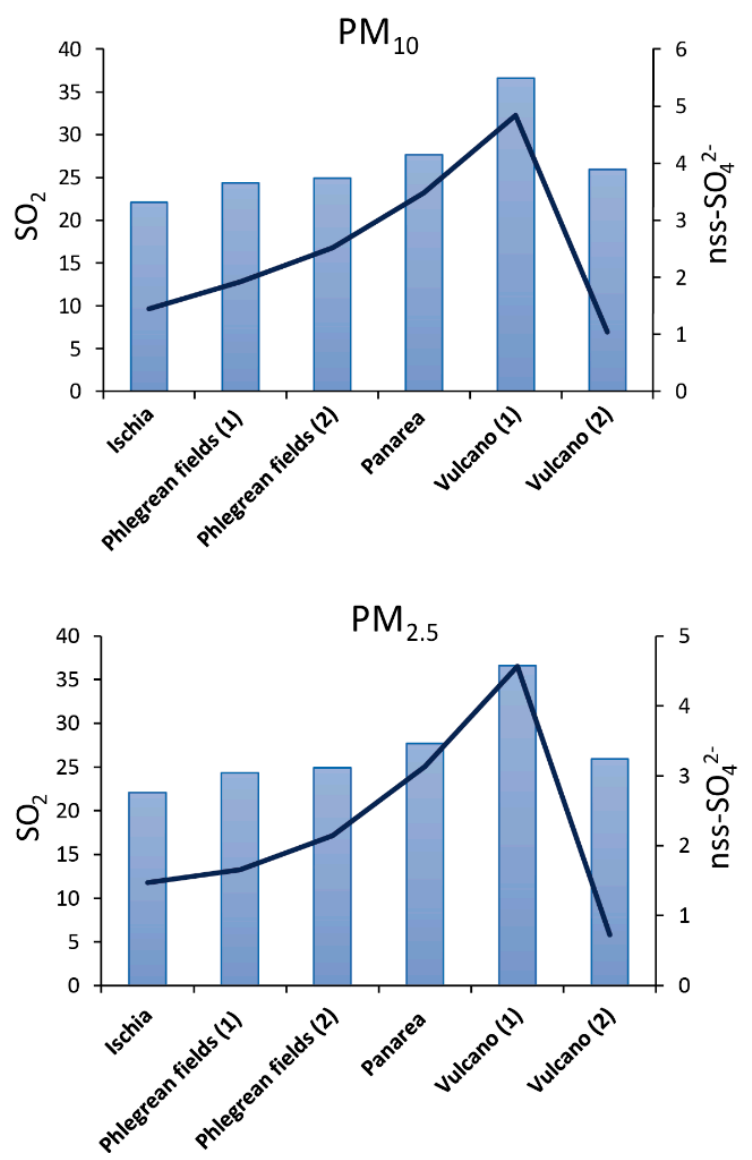

Figure 4. Concentration of sulfur dioxide and sulfate ions (expressed as $\mu \mathrm{g} \mathrm{m}^{-3}$ ) in the fumarolic area. The histogram bars represent $\mathrm{SO}_{2}$ average daily concentrations whereas solid line represents $\mathrm{nss}^{-\mathrm{SO}_{4}}{ }^{2-}$ collected in particulate matter (PM) samples.

As concerns Panarea, although it is a submarine fumarole source, a noteworthy value of both $\mathrm{SO}_{2}$ and nss- $\mathrm{SO}_{4}{ }^{2-}$ was detected, confirming the interception of fumarole degassing process. On the contrary, the analysis of trace metals did not present a significant contribution in PM of the elements typically emitted by natural sources, since they possibly dissolved in the path from the emission site and the seawater surface.

\subsection{Factor Analysis and Source Identification}

We used factor analysis, a tool for source identification and apportionment of particulate air pollutants, to characterize the different sources of aerosols during the campaign. We subjected the dataset to Varimax-rotated factor analysis identifying six factors with Eigenvalues greater than one (Table 1). The six factors together explain $96.9 \%$ of the total variance of our dataset. 
Table 1. Varimax-rotated factor loadings for the whole dataset of the Med-Oceanor 2017 campaign. Loadings greater than 0.5 are shown in bold.

\begin{tabular}{ccccccc}
\hline Variable & Factor1 & Factor2 & Factor3 & Factor4 & Factor5 & Factor6 \\
\hline $\mathrm{PM}_{\mathrm{x}}$ & 0.5 & 0.5 & 0.3 & 0.2 & $\mathbf{0 . 6}$ & -0.3 \\
$\mathrm{OC}$ & $\mathbf{0 . 8}$ & 0.2 & 0.1 & 0.2 & 0.4 & 0.2 \\
$\mathrm{EC}$ & $\mathbf{0 . 9}$ & 0.2 & 0.2 & -0.1 & 0.0 & -0.1 \\
$\mathrm{NH}_{4}{ }^{+}$ & -0.1 & -0.1 & -0.5 & 0.2 & $\mathbf{0 . 8}$ & 0.0 \\
$\mathrm{Al}$ & 0.0 & $\mathbf{0 . 9}$ & 0.0 & 0.2 & 0.2 & -0.4 \\
$\mathrm{Fe}$ & 0.4 & $\mathbf{0 . 8}$ & 0.3 & 0.1 & 0.2 & -0.1 \\
$\mathrm{Na}$ & 0.1 & 0.2 & $\mathbf{0 . 9}$ & -0.2 & -0.2 & 0.0 \\
$\mathrm{Cl}$ & -0.1 & 0.2 & $\mathbf{0 . 7}$ & -0.1 & -0.2 & $-\mathbf{0 . 6}$ \\
$\mathrm{Ca}$ & 0.2 & 0.2 & 0.0 & $\mathbf{0 . 9}$ & 0.1 & 0.0 \\
$\mathrm{Mg}$ & 0.1 & $\mathbf{0 . 6}$ & $\mathbf{0 . 7}$ & 0.0 & 0.1 & -0.2 \\
$\mathrm{P}$ & 0.0 & 0.2 & -0.1 & 1.0 & 0.1 & 0.1 \\
$\mathrm{nss}-\mathrm{SO}{ }_{4}{ }^{2-}$ & 0.1 & 0.3 & -0.1 & 0.1 & $\mathbf{0 . 9}$ & -0.2 \\
$\mathrm{NO}{ }^{-}$ & 0.3 & 0.0 & $\mathbf{0 . 9}$ & -0.1 & -0.3 & 0.0 \\
$\mathrm{~V}$ & 0.4 & 0.2 & -0.4 & -0.2 & $\mathbf{0 . 7}$ & 0.0 \\
$\mathrm{Cr}$ & 0.1 & $\mathbf{0 . 8}$ & 0.5 & -0.1 & 0.0 & 0.2 \\
$\mathrm{Mn}$ & $\mathbf{0 . 7}$ & $\mathbf{0 . 6}$ & -0.2 & 0.2 & 0.0 & 0.2 \\
$\mathrm{Zn}$ & 0.1 & -0.1 & -0.2 & $\mathbf{1 . 0}$ & 0.0 & 0.1 \\
$\mathrm{As}$ & $\mathbf{0 . 8}$ & -0.3 & 0.2 & 0.2 & 0.2 & 0.1 \\
$\mathrm{Sb}$ & $\mathbf{1 . 0}$ & 0.1 & 0.1 & 0.0 & 0.0 & 0.1 \\
$\mathrm{REEs}$ & $\mathbf{0 . 7}$ & -0.1 & 0.0 & 0.0 & -0.1 & $\mathbf{0 . 6}$ \\
$\mathrm{Pb}$ & $\mathbf{0 . 9}$ & 0.3 & 0.0 & 0.1 & 0.0 & 0.3 \\
$\mathrm{Zr}$ & 0.3 & -0.1 & -0.2 & 0.2 & -0.3 & $\mathbf{0 . 9}$ \\
Eigenvalues & 5.7 & 3.8 & 3.7 & 3.1 & 2.8 & 2.1 \\
$\%$ Var & 25.9 & 17.5 & 17.0 & 14.3 & 12.8 & 9.4 \\
$\% \mathrm{Cum}$ & 25.9 & 43.4 & 60.4 & 74.7 & 87.5 & 96.9 \\
\hline & & & & & & \\
\hline
\end{tabular}

- Factor 1: Anthropogenic (pollution). It can be referred to as anthropogenic sources because it has high loadings for carbonaceous material (EC, $\mathrm{OC}), \mathrm{As}, \mathrm{Sb}$, and $\mathrm{Pb}$. This result found a match with intensive vehicular traffic observed during the sampling at the Phlegraean Fields area and is in accordance with the findings reported in Section 4.2.

- Factor 2: Mineral (e.g., soil, African dust, etc.). This factor is characterized by high loadings for $\mathrm{Al}, \mathrm{Fe}, \mathrm{Mg}, \mathrm{Cr}$, and $\mathrm{Mn}$, and can be associated at the first geogenic source (mineral sources) since these elements are common in the crust, basalt of volcanoes, and also in African dust.

- Factor 3: Aged sea salt (marine aerosol). $\mathrm{NO}_{3}{ }^{-}$was added in the FA to describe that this is aged and not fresh sea salt $[37,61]$, indicating that the sampling was not biased by the source of sea spray (limited freshly emitted sea salt particles).

- Factor 4: Factor with unsure attribution. Due to the presence of $\mathrm{Zn}$, it may be attributed to the fumarolic sources [62,63].

- Factor 5: Shipping emissions. This factor can be attributed to the shipping emissions because it has high loadings of $\mathrm{PM}_{\mathrm{x}}, \mathrm{nss}-\mathrm{SO}_{4}{ }^{2-}, \mathrm{NH}_{4}{ }^{+}$and $\mathrm{V}$. The vanadium indeed is used as a tracer of shipping emission [64].

- Factor 6: Rare earth elements. The sixth factor represents a second potential geogenic source characterized by high loadings of $\mathrm{Zr}$ and REEs coming from volcanic ash. Anti-correlated with $\mathrm{Cl}$.

\subsection{SEM/EDX Analysis}

SEM/EDX analysis is utilized as a complementary tool for the quantitative chemical analysis (ICP). The elemental characteristics of aerosols are apportioned based on the respective sources. SEM/EDX confirms that particles with the specified compositions were present in the sampling area and their morphology is defined. Aerosols with a composition common for volcanic particles (e.g., $\mathrm{SiO}_{2}, \mathrm{Mg}$, and $\mathrm{Fe}$ ) have been observed, indicating that they may have originated from the volcanic plume (Figure $5 \mathrm{a}, \mathrm{d}$ ). 
The anthropogenic factor has influenced the sampling (Figure 5f,j) and consequently the experimental results both in terms of chemical and microscopy analysis interpretation (i.e., factor and SEM analysis). In agreement with FA, aged sea salt $(\mathrm{g})$ and several minerals were also observed.

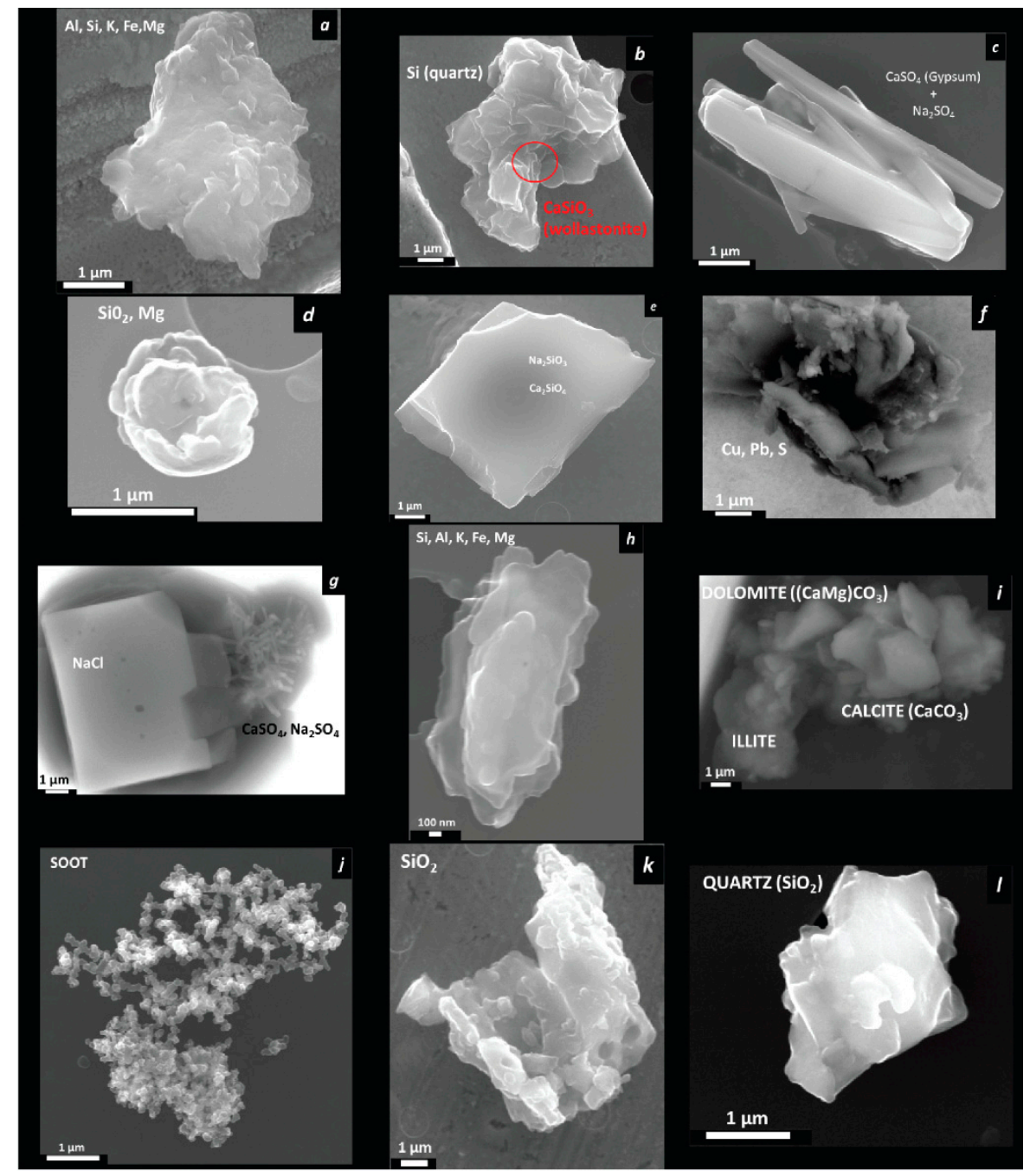

Figure 5. Representative particles sampled from different areas: (a,b) Acicastello, (c,d) Acireale, (e-g) Marsili, (h-k), Phlegraean Fields (1), (1) Stromboli (1).

\subsection{Stepwise Linear Discriminant (S-LDA) Analysis}

To seek which variables best discriminate among samples coming from volcanoes (Vo) and solfatara (So), we performed stepwise linear discriminant analysis (S-LDA). The forward S-LDA (F to enter $=5.00$ and $\mathrm{F}$ to remove $=4.00$ ) retained six elements, namely $\mathrm{Zr}$, As, $\mathrm{Hf}, \mathrm{Bi}, \mathrm{Ca}$, and $\mathrm{Zn}$, that allowed the construction of a model with satisfactory statistical parameters (Wilks' $\lambda=0.09560 ; \mathrm{F}(6,13$ ) $=20.497 ; p<0.00001)$. The low Wilks' $\lambda$ values suggest that the model is highly discriminating, while the low $p$-level value shows that the classification, which resulted correct for all the samples, occurred with high reliability. Based on the partial Wilks' $\lambda, \mathrm{Zn}(0.38)$ is the independent variable that contributes most to the discrimination, followed by Ca (0.50). The scatterplot of canonical scores (Figure S8) on the discriminant function shows the separation between the groups of the volcanic samples (Vo), with negative root values ranging from -4.38 to -1.56 and the solfatara samples (So) with positive root values in the range between 1.39 and 4.69. We found the predominant presence of $\mathrm{Zn}$ in solfatara samples, in accordance to Dekov et al. [32], which detected this element in the aerosol of sulfur-rich sites such as Panarea or other fumarole areas because of its presence as sphalerite ( $\mathrm{ZnS})$. On the contrary, the 
elements Hf and Zr contribute most to characterize volcanic samples. The presence of Hf and Zr agrees with the study of metal emissions from the Stromboli volcano by Allard et al. [51]. Indeed, Hf is one of the elements degassed from magmas as halides, sulfates, sulfides, and/or metals, and is typically found in the aerosol phase of the airborne plume, while the presence of $\mathrm{Zr}$ in volcanic samples can be due to its transport through volcanic ash, supporting the evidence previously obtained from factor analysis.

\section{Conclusions}

In this study, we investigated the impact of volcanic and fumarole sources on PM level and its chemical characteristics in the central Mediterranean Sea. Aerosol samples in marine atmosphere were collected during the research cruise campaign Med-Oceanor 2017 off the coast of the main active volcanic and fumarolic areas in the Mediterranean Sea, which included Mount Etna, the Eolian volcanic arc, Marsili Seamount, and the Phlegraean Fields. The mass concentration of collected PM 10 resulted, for each site, lower than the daily limit set by the European legislation. The $\mathrm{PM}_{10}$ and $\mathrm{PM}_{2.5}$ samples were characterized by quantification of major and trace elements, ionic species, as well as elemental and organic carbon content. These chemical data were illustrated by descriptive statistics, histograms, and then analyzed by the computation of mass closure, enrichment factors, factor analysis, and correlation analysis with the support of the daily $\mathrm{SO}_{2}$ values. The $\mathrm{PM}_{10}$ mainly consisted of carbonaceous material and dust, which together made up over $50 \%$ of the mass, while carbonaceous fraction and SIA, which reached $60 \%$ of the mass, prevalently composed the $\mathrm{PM}_{2.5}$. The trace element was the less abundant contributor with an average amount of about $1 \%$ in both PM fractions. From the EFs, we found that the particulate from the volcanic areas resulted enriched by $\mathrm{Tl}, \mathrm{Cu}, \mathrm{La}$, Se, As, and alkali metals, whereas the chemical characterization of PM in fumarole areas showed a good correlation between the sulfur dioxide gas, emitted from fumaroles and sulfate ion, coming from the $\mathrm{SO}_{2}$ reaction with water and condensation on particles. FA allowed for the identification of six potential sources that contribute to the PM composition, some of which have a natural origin such as volcanic, marine, and geogenic emissions, while other sources are anthropogenic, such as combustion processes, vehicular traffic, and shipping emissions. The SEM/EDX analysis on the sampled PM confirmed the influence of these sources identified with the FA. Stepwise linear discriminant analysis (S-LDA), which was used to seek for a model capable to discriminate between the sample of volcanic and fumarolic origin, pointed out the elements that discriminate the most between these two classes, namely $\mathrm{Hf}$ and $\mathrm{Zr}$ for volcano samples and $\mathrm{Zn}$ and Ca for solfatara samples.

Further investigation on this topic could be addressed in future research for a more thorough assessment of the impact of the volcanic and fumarolic emission on the air quality of the Mediterranean Sea. In this regard, the use of a high-volume sampler would allow sampling the PM with sufficient sensitivity even with a few hours of collection, thus improving the temporal profile of the impact. Similarly, further advancement of the study would be given by the use of cascade impactors, whose data could provide new insight to strengthen the characterization of the marine atmosphere in the neighborhood of volcanoes and fumaroles.

Supplementary Materials: The following are available online at http://www.mdpi.com/2073-4433/11/2/149/s1, Figure S1: Hourly mean meteorological data; Temperature and Pressure (up) and wind speed (down), Figure S2: Wind roses for sampling points, Figure S3: NCEP/NCAR reanalysis maps (mean and anomaly) of the period from the start of the campaign to 31 August (up) and 2 September (down), Figure S4: Acireale maps NAAPS, air mass back trajectory and BSC-Dream, Figure S5: Time series plot of $\mathrm{SO}_{2}$ for each of the sampling sites; Y-axis: concentration (ppb), X-axis: sampling time (hours), Figure S6: Enrichment Factors for Etna (Acicastello sample) and Stromboli (Stromboli (3) sample). Dashed lines highlight thresholds for EFs $=10$ and EFs $=100$, Figure S7: Correlation between $\mathrm{SO}_{2}$ and nss- $\mathrm{SO}_{4}{ }^{2-}\left(\right.$ as $\mu \mathrm{g} \mathrm{m}{ }^{-3}$ ) in $\mathrm{PM}_{10}$ and $\mathrm{PM}_{2.5}$. The plots (a) and (b) comprise all the sampling points, whereas the Vulcano (2) sample is excluded in (c) and (d) plots the plots., Figure S8: LDA scatterplot for aerosol samples collected in volcanic (Vo) or solfatara (So) sites, Table S1: Percentage chemical composition of $\mathrm{PM}_{10}$ and $\mathrm{PM}_{2.5}$ in each sampling site.

Author Contributions: S.M., Conceptualization, investigation, writing—original draft preparation, writingreview and editing; A.S., investigation, writing—review and editing; X.Q., conceptualization, supervision; A.T., conceptualization, writing—original draft preparation, writing—review and editing; V.A., investigation; M.B., 
conceptualization; N.P., funding acquisition; F.S., funding acquisition, supervision; A.N., conceptualization, writing-review and editing, supervision, All authors have read and agreed to the published version of the manuscript.

Funding: This research was funded by the European Commission-H2020, the ERA-PLANET programme (www.era-planet.eu; contract no. 689443) within the IGOSP project (www.igosp.eu).

Acknowledgments: The authors are grateful to Valentino Mannarino and Giulio Esposito for the logistic support in the Med-Oceanor campaign.

Conflicts of Interest: The authors declare no conflicts of interest.

\section{References}

1. Lelieveld, J.; Evans, J.S.; Fnais, M.; Giannadaki, D.; Pozzer, A. The contribution of outdoor air pollution sources to premature mortality on a global scale. Nature 2015, 525, 367-371. [CrossRef]

2. Viana, M.; Pey, J.; Querol, X.; Alastuey, A.; de Leeuw, F.; Lükewille, A. Natural sources of atmospheric aerosols influencing air quality across Europe. Sci. Total Environ. 2014, 472, 825-833. [CrossRef]

3. Naccarato, A.; Tassone, A.; Moretti, S.; Elliani, R.; Sprovieri, F.; Pirrone, N.; Tagarelli, A. A green approach for organophosphate ester determination in airborne particulate matter: Microwave-assisted extraction using hydroalcoholic mixture coupled with solid-phase microextraction gas chromatography-tandem mass spectrometry. Talanta 2018, 189, 657-665. [CrossRef]

4. Naccarato, A.; Elliani, R.; Sindona, G.; Tagarelli, A. Multivariate optimization of a microextraction by packed sorbent-programmed temperature vaporization-gas chromatography-tandem mass spectrometry method for organophosphate flame retardant analysis in environmental aqueous matrices. Anal. Bioanal. Chem. 2017, 409, 7105-7120. [CrossRef]

5. Talarico, F.; Brandmayr, P.; Giulianini, P.G.; Ietto, F.; Naccarato, A.; Perrotta, E.; Tagarelli, A.; Giglio, A. Effects of metal pollution on survival and physiological responses in Carabus (Chaetocarabus) lefebvrei (Coleoptera, Carabidae). Eur. J. Soil Biol. 2014, 61, 80-89. [CrossRef]

6. Aleksandropoulou, V.; Torseth, K.; Lazaridis, M. Contribution of natural sources to PM emissions over the metropolitan areas of athens and Thessaloniki. Aerosol Air Qual. Res. 2015, 15, 1300-1312. [CrossRef]

7. Bencardino, M.; Andreoli, V.; D'Amore, F.; DeSimone, F.; Mannarino, V.; Castagna, J.; Moretti, S.; Naccarato, A.; Sprovieri, F.; Pirrone, N. Carbonaceous Aerosols Collected at the Observatory of Monte Curcio in the Southern Mediterranean Basin. Atmosphere 2019, 10, 592. [CrossRef]

8. Bencardino, M.M.; Pirrone, N.N.; Sprovieri, F.F. Aerosol and ozone observations during six cruise campaigns across the Mediterranean basin: temporal, spatial, and seasonal variability. Environ. Sci. Pollut. Res. 2014, 21, 4044-4062. [CrossRef] [PubMed]

9. Beuck, H.; Quass, U.; Klemm, O.; Kuhlbusch, T.A.J. Assessment of sea salt and mineral dust contributions to PM10 in NW Germany using tracer models and positive matrix factorization. Atmos. Environ. 2011, 45, 5813-5821. [CrossRef]

10. Dinoi, A.; Cesari, D.; Marinoni, A.; Bonasoni, P.; Riccio, A.; Chianese, E.; Tirimberio, G.; Naccarato, A.; Sprovieri, F.; Andreoli, V.; et al. Inter-comparison of carbon content in PM2.5 and PM10 collected at five measurement sites in Southern Italy. Atmosphere 2017, 8, 243. [CrossRef]

11. Liora, N.; Poupkou, A.; Giannaros, T.M.; Kakosimos, K.E.; Stein, O.; Melas, D. Impacts of natural emission sources on particle pollution levels in Europe. Atmos. Environ. 2016, 137, 171-185. [CrossRef]

12. Masson, O.; Piga, D.; Gurriaran, R.; D'Amico, D. Impact of an exceptional Saharan dust outbreak in France: PM10 and artificial radionuclides concentrations in air and in dust deposit. Atmos. Environ. 2010, 44, 2478-2486. [CrossRef]

13. Querol, X.; Pey, J.; Pandolfi, M.; Alastuey, A.; Cusack, M.; Pérez, N.; Moreno, T.; Viana, M.; Mihalopoulos, N.; Kallos, G.; et al. African dust contributions to mean ambient PM10 mass-levels across the Mediterranean Basin. Atmos. Environ. 2009, 43, 4266-4277. [CrossRef]

14. Bencardino, M.; Sprovieri, F.; Cofone, F.; Pirrone, N. Variability of atmospheric aerosol and ozone concentrations at marine, urban, and high-altitude monitoring stations in southern Italy during the 2007 summer Saharan dust outbreaks and wildfire episodes. J. Air Waste Manag. Assoc. 2011, 61, 952-967. [CrossRef] [PubMed] 
15. Pey, J.; Alastuey, A.; Querol, X. PM10and PM2.5sources at an insular location in the western mediterranean by using source apportionment techniques. Sci. Total Environ. 2013, 456, 267-277. [CrossRef]

16. O'Dowd, C.D.; de Leeuw, G. Marine aerosol production: a review of the current knowledge. Philos. Trans. R. Soc. A Math. Phys. Eng. Sci. 2007, 365, 1753-1774. [CrossRef] [PubMed]

17. Faustini, A.; Alessandrini, E.R.; Pey, J.; Perez, N.; Samoli, E.; Querol, X.; Cadum, E.; Perrino, C.; Ostro, B.; Ranzi, A.; et al. Short-term effects of particulate matter on mortality during forest fires in Southern Europe: Results of the MED-PARTICLES project. Occup. Environ. Med. 2015, 72, 323-329. [CrossRef]

18. von Glasow, R. Atmospheric chemistry in volcanic plumes. Proc. Natl. Acad. Sci. 2010, 107, $6594-6599$. [CrossRef]

19. Helbert, J. Fumarole. In Encyclopedia of Astrobiology; Gargaud, M., Amils, R., Quintanilla, J.C., Cleaves, H.J., Irvine, W.M., Pinti, D.L., Viso, M., Eds.; Springer Berlin Heidelberg: Berlin, Germany, 2011; p. 617, ISBN 978-3-642-11274-4.

20. Intergovernmental Panel on Climate Change Summary for Policymakers. In Climate Change 2013 - The Physical Science Basis; Intergovernmental Panel on Climate Change (Ed.) Cambridge University Press: Cambridge, UK, 2013; pp. 1-30, ISBN 9788578110796.

21. Arndt, J.; Calabrese, S.; D’Alessandro, W.; Planer-Friedrich, B. Using mosses as biomonitors to study trace element emissions and their distribution in six different volcanic areas. J. Volcanol. Geotherm. Res. 2017, 343, 220-232. [CrossRef]

22. Bagnato, E.; Aiuppa, A.; Andronico, D.; Cristaldi, A.; Liotta, M.; Brusca, L.; Miraglia, L. Leachate analyses of volcanic ashes from Stromboli volcano: A proxy for the volcanic gas plume composition? J. Geophys. Res. Atmos. 2011, 116, 1-17. [CrossRef]

23. Calabrese, S.; Aiuppa, A.; Allard, P.; Bagnato, E.; Bellomo, S.; Brusca, L.; D'Alessandro, W.; Parello, F. Atmospheric sources and sinks of volcanogenic elements in a basaltic volcano (Etna, Italy). Geochim. Cosmochim. Acta 2011, 75, 7401-7425. [CrossRef]

24. Chouet, B.; Dawson, P.; Ohminato, T.; Martini, M.; Saccorotti, G.; Giudicepietro, F.; De Luca, G.; Milana, G.; Scarpa, R. Source mechanisms of explosions at Stromboli Volcano, Italy, determined from moment-tensor inversions of very-long-period data. J. Geophys. Res. Solid Earth 2003, 108, ESE 7-1-ESE 7-25. [CrossRef]

25. Castagna, J.; Bencardino, M.; D'Amore, F.; Esposito, G.; Pirrone, N.; Sprovieri, F. Atmospheric mercury species measurements across the Western Mediterranean region: Behaviour and variability during a 2015 research cruise campaign. Atmos. Environ. 2018, 173, 108-126. [CrossRef]

26. Pirrone, N.; Ferrara, R.; Hedgecock, I.M.; Kallos, G.; Mamane, Y.; Munthe, J.; Pacyna, J.M.; Pytharoulis, I.; Sprovieri, F.; Voudouri, A.; et al. Dynamic processes of mercury over the Mediterranean region: Results from the Mediterranean Atmospheric Mercury Cycle System (MAMCS) project. Atmos. Environ. 2003, 37, 21-39. [CrossRef]

27. Chester, D.K.; Duncan, A.M.; Guest, J.E.; Kilburn, C.R.J. Mount Etna; Springer: Dordrecht, The Netherlands, 1986; ISBN 978-94-010-8309-6.

28. Finizola, A.; Sortino, F.; Lénat, J.F.; Aubert, M.; Ripepe, M.; Valenza, M. The summit hydrothermal system of Stromboli. New insights from self-potential, temperature, $\mathrm{CO}_{2}$ and fumarolic fluid measurements, with structural and monitoring implications. Bull. Volcanol. 2003, 65, 486-504. [CrossRef]

29. Italiano, F.; De Santis, A.; Favali, P.; Rainone, M.; Rusi, S.; Signanini, P.; Italiano, F.; De Santis, A.; Favali, P.; Rainone, M.L.; et al. The Marsili Volcanic Seamount (Southern Tyrrhenian Sea): A Potential Offshore Geothermal Resource. Energies 2014, 7, 4068-4086. [CrossRef]

30. Trua, T.; Serri, G.; Marani, M.; Renzulli, A.; Gamberi, F. Volcanological and petrological evolution of Marsili Seamount (southern Tyrrhenian Sea). J. Volcanol. Geotherm. Res. 2002, 114, 441-464. [CrossRef]

31. Caratori Tontini, F.; Cocchi, L.; Muccini, F.; Carmisciano, C.; Marani, M.; Bonatti, E.; Ligi, M.; Boschi, E. Potential-field modeling of collapse-prone submarine volcanoes in the southern Tyrrhenian Sea (Italy). Geophys. Res. Lett. 2010, 37, 1-5. [CrossRef]

32. Dekov, V.M.; Kamenov, G.D.; Savelli, C.; Stummeyer, J. Anthropogenic Pb component in hydrothermal ochres from Marsili Seamount (Tyrrhenian Sea). Mar. Geol. 2006, 229, 199-208. [CrossRef]

33. Chiodini, G.; Avino, R.; Brombach, T.; Caliro, S.; Cardellini, C.; De Vita, S.; Frondini, F.; Granirei, D.; Marotta, E.; Ventura, G. Fumarolic and diffuse soil degassing west of Mount Epomeo, Ischia, Italy. J. Volcanol. Geotherm. Res. 2004, 133, 291-309. [CrossRef] 
34. Italiano, F.; Nuccio, P.M. Geochemical investigations of submarine volcanic exhalations to the east of Panarea, Aeolian Islands, Italy. J. Volcanol. Geotherm. Res. 1991, 46, 125-141. [CrossRef]

35. Caracausi, A.; Ditta, M.; Italiano, F.; Longo, M.; Nuccio, P.M.; Paonita, A.; Rizzo, A. Changes in fluid geochemistry and physico-chemical conditions of geothermal systems caused by magmatic input: The recent abrupt outgassing off the island of Panarea (Aeolian Islands, Italy). Geochim. Cosmochim. Acta 2005, 69, 3045-3059. [CrossRef]

36. Cavalli, F.; Viana, M.; Yttri, K.E.; Genberg, J.; Putaud, J.P. Toward a standardised thermal-optical protocol for measuring atmospheric organic and elemental carbon: The EUSAAR protocol. Atmos. Meas. Tech. 2010, 3, 79-89. [CrossRef]

37. Querol, X.; Alastuey, A.; Rodriguez, S.; Plana, F.; Ruiz, C.R.; Cots, N.; Massagué, G.; Puig, O. PM10 and PM2.5 source apportionment in the Barcelona Metropolitan area, Catalonia, Spain. Atmos. Environ. 2001, 35, 6407-6419. [CrossRef]

38. Amato, F.; Pandolfi, M.; Escrig, A.; Querol, X.; Alastuey, A.; Pey, J.; Perez, N.; Hopke, P.K.K. Quantifying road dust resuspension in urban environment by Multilinear Engine: A comparison with PMF2. Atmos. Environ. 2009, 43, 2770-2780. [CrossRef]

39. Salmatonidis, A.; Ribalta, C.; Sanfélix, V.; Bezantakos, S.; Biskos, G.; Vulpoi, A.; Simion, S.; Monfort, E.; Viana, M. Workplace Exposure to Nanoparticles during Thermal Spraying of Ceramic Coatings. Ann. Work Expo. Health 2019, 63, 91-106. [CrossRef]

40. Salmatonidis, A.; Viana, M.; Pérez, N.; Alastuey, A.; de la Fuente, G.F.; Angurel, L.A.; Sanfélix, V.; Monfort, E. Nanoparticle formation and emission during laser ablation of ceramic tiles. J. Aerosol Sci. 2018, 126, 152-168. [CrossRef]

41. Seinfeld, J.H.; Pandis, S.N. Atmospheric Chemistry and Physics; From Air Pollution to Climate Change; John Wiley \& Sons: New York, NY, USA, 2006; ISBN 978-0-471-72018-8.

42. Mason, B. Principles of geochemistry, 3rd ed.; JohnWiley\&Sons, Inc.: New York, NY, USA, 1966.

43. Chow, J.C.; Watson, J.G.; Edgerton, S.A.; Vega, E. Chemical composition of PM2.5 and PM10 in Mexico City during winter 1997. Sci. Total. Environ. 2002, 287, 177-201. [CrossRef]

44. Robinson, A.L.; Grieshop, A.P.; Donahue, N.M.; Hunt, S.W. Updating the conceptual model for fine particle mass emissions from combustion systems. J. Air Waste Manag. Assoc. 2010, 60, 1204-1222. [CrossRef]

45. Roy, A.A.; Wagstrom, K.M.; Adams, P.J.; Pandis, S.N.; Robinson, A.L. Quantification of the effects of molecular marker oxidation on source apportionment estimates for motor vehicles. Atmos. Environ. 2011, 45, 3132-3140. [CrossRef]

46. Turpin, B.J.; Lim, H.-J. Species Contributions to PM2.5 Mass Concentrations: Revisiting Common Assumptions for Estimating Organic Mass. Aerosol Sci. Technol. 2001, 35, 602-610. [CrossRef]

47. Cheung, K.; Daher, N.; Kam, W.; Shafer, M.M.; Ning, Z.; Schauer, J.J.; Sioutas, C. Spatial and temporal variation of chemical composition and mass closure of ambient coarse particulate matter (PM10-2.5) in the Los Angeles area. Atmos. Environ. 2011, 45, 2651-2662. [CrossRef]

48. Mkoma, S.L.; Maenhaut, W.; Chi, X.; Wang, W.; Raes, N. Characterisation of PM10 atmospheric aerosols for the wet season 2005 at two sites in East Africa. Atmos. Environ. 2009, 43, 631-639. [CrossRef]

49. Stein, A.F.; Draxler, R.R.; Rolph, G.D.; Stunder, B.J.B.; Cohen, M.D.; Ngan, F.; Stein, A.F.; Draxler, R.R.; Rolph, G.D.; Stunder, B.J.B.; et al. NOAA's HYSPLIT Atmospheric Transport and Dispersion Modeling System. Bull. Am. Meteorol. Soc. 2015, 96, 2059-2077. (Hybrid Single-Particle Lagrangian Integrated Trajectories model). Available online: http://ready.arl.noaa.gov/HYSPLIT.php (accessed on 5 June 2018). [CrossRef]

50. Pérez, C.; Nickovic, S.; Pejanovic, G.; Baldasano, J.M.; Özsoy, E. Interactive dust-radiation modeling: A step to improve weather forecasts. J. Geophys. Res. Atmos. 2006, 111. (BSC Dust Regional Atmospheric Model). Available online: www.bsc.es/projects/earthscience/DREAM/ (accessed on 5 June 2018). [CrossRef]

51. Allard, P.; Aiuppa, A.; Loyer, H.; Carrot, F.; Gaudry, A.; Pinte, G.; Michel, A.; Dongarrà, G. Acid gas and metal emission rates during long-lived basalt degassing at Stromboli volcano. Geophys. Res. Lett. 2000, 27, 1207-1210. [CrossRef]

52. Kalnay, E.; Kanamitsu, M.; Kistler, R.; Collins, W.; Deaven, D.; Gandin, L.; Iredell, M.; Saha, S.; White, G.; Woollen, J.; et al. The NCEP/NCAR 40-Year Reanalysis Project. Bull. Am. Meteorol. Soc. 1996, 77, 437-471. [CrossRef] 
53. Laussac, S.; Piazzola, J.; Tedeschi, G.; Yohia, C.; Canepa, E.; Rizza, U.; Van Eijk, A.M.J. Development of a fetch dependent sea-spray source function using aerosol concentration measurements in the North-Western Mediterranean. Atmos. Environ. 2018, 193, 177-189. [CrossRef]

54. Mather, T.A.; Oppenheimer, C.; Allen, A.G.; McGonigle, A.J.S. Aerosol chemistry of emissions from three contrasting volcanoes in Italy. Atmos. Environ. 2004, 38, 5637-5649. [CrossRef]

55. Aiuppa, A.; Dongarrà, G.; Valenza, M.; Federico, C.; Pecoraino, G. Degassing of Trace Volatile Metals During The 2001 Eruption of Etna. In Geophysical Monograph Series; American Geophysical Union: Washington, DC, USA, 2003; Volume 139, pp. 41-54, ISBN 9781118668542.

56. Allen, A.G.; Mather, T.A.; McGonigle, A.J.S.; Aiuppa, A.; Delmelle, P.; Davison, B.; Bobrowski, N.; Oppenheimer, C.; Pyle, D.M.; Inguaggiato, S. Sources, size distribution, and downwind grounding of aerosols from Mount Etna. J. Geophys. Res. Atmos. 2006, 111, 1-10. [CrossRef]

57. Bagnato, E.; Aiuppa, A.; Parello, F.; Calabrese, S.; D'Alessandro, W.; Mather, T.A.; McGonigle, A.J.S.; Pyle, D.M.; Wängberg, I. Degassing of gaseous (elemental and reactive) and particulate mercury from Mount Etna volcano (Southern Italy). Atmos. Environ. 2007, 41, 7377-7388. [CrossRef]

58. Moreno, T.; Querol, X.; Castillo, S.; Alastuey, A.; Cuevas, E.; Herrmann, L.; Mounkaila, M.; Elvira, J.; Gibbons, W. Geochemical variations in aeolian mineral particles from the Sahara-Sahel Dust Corridor. Chemosphere 2006, 65, 261-270. [CrossRef] [PubMed]

59. Reimann, C.; De Caritat, P. Intrinsic flaws of element enrichment factors (EFs) in environmental geochemistry. Environ. Sci. Technol. 2000, 34, 5084-5091. [CrossRef]

60. Aiuppa, A.; Allard, P.; D'Alessandro, W.; Michel, A.; Parello, F.; Treuil, M.; Valenza, M. Mobility and fluxes of major, minor and trace metals during basalt weathering and groundwater transport at Mt. Etna volcano (Sicily). Geochim. Cosmochim. Acta 2000, 64, 1827-1841. [CrossRef]

61. Piazzola, J.; Mihalopoulos, N.; Canepa, E.; Tedeschi, G.; Prati, P.; Zarmpas, P.; Bastianini, M.; Missamou, T.; Cavaleri, L. Characterization of aerosols above the Northern Adriatic Sea: Case studies of offshore and onshore wind conditions. Atmos. Environ. 2016, 132, 153-162. [CrossRef]

62. Marani, M.P.; Gamberi, F.; Savelli, C. Shallow-water polymetallic sulfide deposits in the Aeolian island arc. Geology 1997, 25, 815-818. [CrossRef]

63. Savelli, C.; Marani, M.; Gamberi, F. Geochemistry of metalliferous, hydrothermal deposits in the Aeolian arc (Tyrrhenian Sea). J. Volcanol. Geotherm. Res. 1999, 88, 305-323. [CrossRef]

64. Viana, M.; Kuhlbusch, T.A.J.; Querol, X.; Alastuey, A.; Harrison, R.M.; Hopke, P.K.; Winiwarter, W.; Vallius, M.; Szidat, S.; Prévôt, A.S.H.; et al. Source apportionment of particulate matter in Europe: A review of methods and results. J. Aerosol Sci. 2008, 39, 827-849. [CrossRef] 